\title{
Apoptosis signalling mechanisms in human cancer cells induced by Calphostin-PDT
}

\author{
MALINI OLIVO ${ }^{1,2}$ and MOHAMED ALI-SEYED 3 \\ ${ }^{1}$ Division of Medical Sciences, National Cancer Centre, 11 Hospital Drive; \\ ${ }^{2}$ Department of Pharmacy, National University of Singapore, 10 Kent Ridge Road, Singapore; \\ ${ }^{3}$ Department of Pathology and Laboratory Medicine, Emory University, Atlanta, GA, USA
}

Received July 11, 2006; Accepted November 3, 2006

\begin{abstract}
Photodynamic therapy (PDT) is a promising treatment that is approved by the US FDA for the treatment of oesophageal and lung cancer as well as for age-related macular degeneration. In this study, using standard tissue culture techniques, the photo cytotoxicity and apoptotic mechanisms of Calphostin $\mathrm{C}(\mathrm{Cal} \mathrm{C})$, a perylenequinone microbial compound in combination with visible light dose was examined in different tumor cell lines. Our results demonstrated both a time and drug-light dose dependence in Cal-C-PDT induced photo toxicity and apoptotic cell death. The induction of apoptosis by Cal C-PDT was found to transit to necrotic cell death at higher drug and light doses. The detection of apoptosis in irradiated tumor cells was performed using various approaches including cell morphology analysis, flow cytometry [DNA fragmentation and phosphatidylserine (PS) externalization] and biochemical assays (activation of caspases). Time-course analysis of Cal $\mathrm{C}$ cellular uptake and distribution showed a rapid increase within the cellular compartments. The activation of caspases and nuclear fragmentation was evidenced at a maximum time point of $3 \mathrm{~h}$ after irradiation. By the use of specific caspase substrates, significant activation of caspase- 8 and -3 was found. Mitochondrial involvement during Cal C-PDT-induced apoptosis was proven by a rapid reduction of the mitochondrial membrane potential. Furthermore, Cal C-PDT also enhanced FasL expression, which then induced Fas signalling-dependent cell death in NPC and colon cancer cell lines tested. Our results contribute to a deeper understanding of the processes involved in apoptotic cell death following photodynamic treatment with Cal C.
\end{abstract}

Correspondence to: Dr Malini Olivo, Division of Medical Sciences, National Cancer Centre, 11 Hospital Drive, Singapore 169610

E-mail:dmsmcd@nccs.com.sg

Key words: photodynamic therapy, Calphostin C, caspases nasopharyngeal carcinoma, apoptosis

\section{Introduction}

Photodynamic therapy involves a sensitizer, light and oxygen to induce cell death in neoplasms $(1,2)$. Cell death in PDT may occur by apoptosis or necrosis, depending on the sensitizer, PDT drug-light dose and on the cell genotype (3). Some sensitizers that have been used in PDT are accumulated in the organelles including mitochondria, and this may explain their efficiency in inducing apoptotic cell death, both in vitro and in vivo (4-7). This study focuses on the events that characterize apoptotic death in PDT and on the intracellular signalling events that are set in motion in photosensitized cells using the novel photosensitizer Calphostin $\mathrm{C}(\mathrm{Cal} \mathrm{C})$.

$\mathrm{Cal} \mathrm{C}$, is a member of the class of 4,9-dihydroxy-3, 10 perylenequinones isolated from Cladosporium cladosporioides and has been used extensively as a specific inhibitor of protein kinase C (PKC) (8). It has been reported that perylenequinone sensitizers have superior PDT efficiency because of their special characteristics such as ease of purification, significantly reduced normal tissue/cell photosensitivity, fast metabolism, and a small aggregation tendency (9). Based on these properties, it has been proposed that $\mathrm{Cal} \mathrm{C}$ may have applications as a photosensitizing $(10,11)$ and anti-cancer agent $(12)$. Some studies $(13,14)$ support the findings that perylenequinone $\mathrm{Cal} \mathrm{C}$ induce apoptosis in tumor cell lines but the specific molecular mechanism involved have not been reported.

Although Cal $\mathrm{C}$ has been added as a new agent for PDT, the signalling mechanisms involved in PDT mediated apoptosis using $\mathrm{Cal} \mathrm{C}$ is just emerging and the main mechanisms of phototoxicity induced are still not understood $(11,15,16)$. The present study reveals for the first time that the involvement of the death receptor in the induction of apoptosis in Cal C photosensitized cells. Our results demonstrate that the phototoxicity of $\mathrm{Cal} \mathrm{C}$ from low to high concentration is exquisitely light dependent. Cells treated with $\mathrm{Cal} \mathrm{C}$ in the presence of visible light exhibit characteristic apoptotic features. By using spectrofluorimetry and confocal laser scanning microscopy (CLSM) we have determined cellular fluorescence localization and uptake of Cal C. It has been well characterized that localization and the cellular uptake of sensitizers play an important role in the induction of apoptosis and cell death (17-19). 
We report herein the findings showing that photoactivated Cal $\mathrm{C}$ induces apoptotic cell death in NPC as well as other types of tumor cells at doses not toxic to normal fibroblast cells. Cal $\mathrm{C}$ induced apoptosis is mediated via caspase activation and $\mathrm{Cal} \mathrm{C}$ enhances FasL expression, which induces Fas signalling-dependent cell death in NPC and colon cancer cell lines studied.

\section{Materials and methods}

Cells and culture conditions. Poorly differentiated CNE2 and moderately differentiated TWO-1 human nasopharyngeal cell lines (NPC) were kindly provided by Professor K.M. Hui, National Cancer Centre, Singapore and Dr C.T. Lin, National Taiwan University Hospital, Taipei, Taiwan, respectively. Colon cells (CCL-220.1, designation: COLO 320HSR) were obtained from American Tissue Culture Collection (ATCC, Rockville, MD, USA) and bladder epithelial (SD) cells were kindly provided by Dr J.R. Masters, London, UK.

Chemicals. Calphostin C (Cal C), propidium iodide (PI), crystal violet, and RNAse A were obtained from Sigma Chemical Co. (St. Louis, MO, USA). The caspases inhibitor peptide, benzyloxycarbonyl-Asp-Glu-Val-Asp-fluoromethylketone (z-VAD-fmk) was obtained from Calbiochem-Inalco (Milan, Italy), dissolved as stock solution in dimethylsulfoxide (DMSO) and stored at $-20^{\circ} \mathrm{C}$. Annexin-fluorescein isothiocyanate (FITC) and DEVD-CHO (Ac-DEVD-CHO, acetylAsp-Glu-Val-Asp aldehyde) were purchased from Clontech Laboratories, Inc. (Palo Alto, CA, USA). Anti-PARP monoclonal antibody (C-2-10) was obtained from Biomol Research Laboratories, Inc. (Plymouth Meeting, PA, USA).

Photosensitizers and light source. The photosensitizer, Cal C was obtained from Sigma Chemical Co. Stock solution of Cal C was made in DMSO at a concentration of $1 \mathrm{mM} / \mathrm{ml}$. Working dilutions were directly made in the tissue culture medium. For the PDT treatments, tissue culture 6- or 96-well plates containing cell monolayers were incubated with or without Cal C. The plates were then irradiated on a 100x50 cm light-diffusing surface illuminated by a bank of 14 fluorescent tubes (Phillips type OSRAM L30W11-860, 30W), and filtered with red acetate filters (No. 17 Roscolux, CA, USA) in order to receive a wide band illumination $>585 \mathrm{~nm}$. The energy fluence rate was $10 \mathrm{Wm}^{2}$ in the wavelength band $580-620 \mathrm{~nm}$ comprising $12 \%$ of the total filtered output. The cells were irradiated for a fixed time to give light energy fluence of $0.4 \mathrm{~J} / \mathrm{cm}^{2}$. Light intensities were quantitated using an IL 1400 radiometer (International light, Newburyport, MA, USA).

Cell survival and uptake assays. NPC (CNE2 and TW0-1), colon (CCL-220.1) and bladder (SD) cells respectively were incubated with different concentrations of $\mathrm{Cal} \mathrm{C}$ in the dark for specific times and cells were further analyzed for $\mathrm{Cal} \mathrm{C}$ cellular distribution, uptake and clearance. For cell survival experiments, cells were plated in a 96-well plate at $2 \times 10^{4}$ cells per well and were incubated with $37.5-150 \mathrm{~nm} / \mathrm{ml}$ of $\mathrm{Cal} \mathrm{C}$ for $2 \mathrm{~h}$. After $2 \mathrm{~h}$ of drug incubation, fresh drug-free growth medium was replaced, and cells were exposed to red light at the dose of $0.4 \mathrm{~J} / \mathrm{cm}^{2}$ and kept in the dark. After $18 \mathrm{~h}$

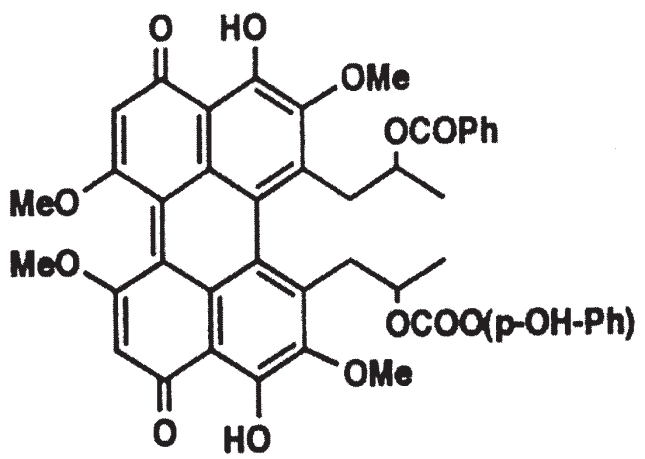

Figure 1. Chemical structure of Caphostin C.

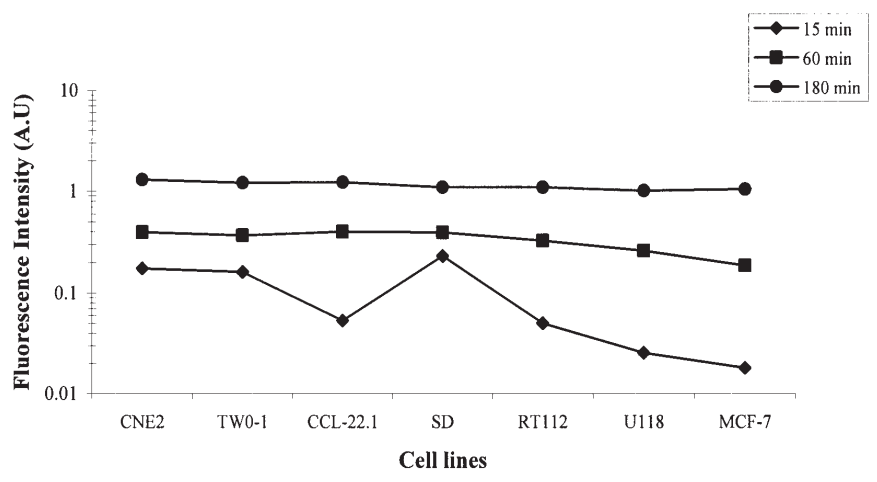

Figure 2. The relative fluorescence intensities of the photosensitizer $\mathrm{Cal} \mathrm{C}$ was measured by spectrofluorimetry to show as a function of uptake kinetics. Representative fluorescence intensity of each cell line at indicated time points is presented.

of incubation, loss of monolayer adherence was measured with crystal fast violet (CFV) staining and cell survival was and expressed as a percentage. To further confirm that the loss of viability obtained by the CFV assay was indeed due to apoptosis, cells grown on chamber slides with $\mathrm{Cal} \mathrm{C}$ were irradiated as described above, following which they were stained with Hoechst 33342 and examined by confocal microscopy.

Analysis of Fas and FasL expression and mitochondrial transmembrane potential. Immunofluorescence staining for Fas and FasL was performed as described by Villunger et al and Ali et al $(20,21)$. We then examined the changes in mitochondrial transmembrane potential $(\Delta \Psi \mathrm{m})$, if any, during PDT induced killing using green-fluorescent lipophilic cationic dye 3,3'dihexyloxacarbocyanine iodide (DiOC6) (22) by flow cytometry (23).

Caspase activity, DNA fragmentation and phosphatidylserine $(P S)$ translocation. Caspases 8 and 3 activity in Cal C-treated cells was analyzed as described earlier $(7,20)$. Representative cell lines (CNE2 and TWO-1) were treated with Cal C $(75-150 \mathrm{~nm})$ and subjected to light exposure as mentioned in Materials and methods. The results show the many-fold increase in fluorescence relative to the drug-treated but nonirradiated control cells. Caspase- 3 activity was shown 

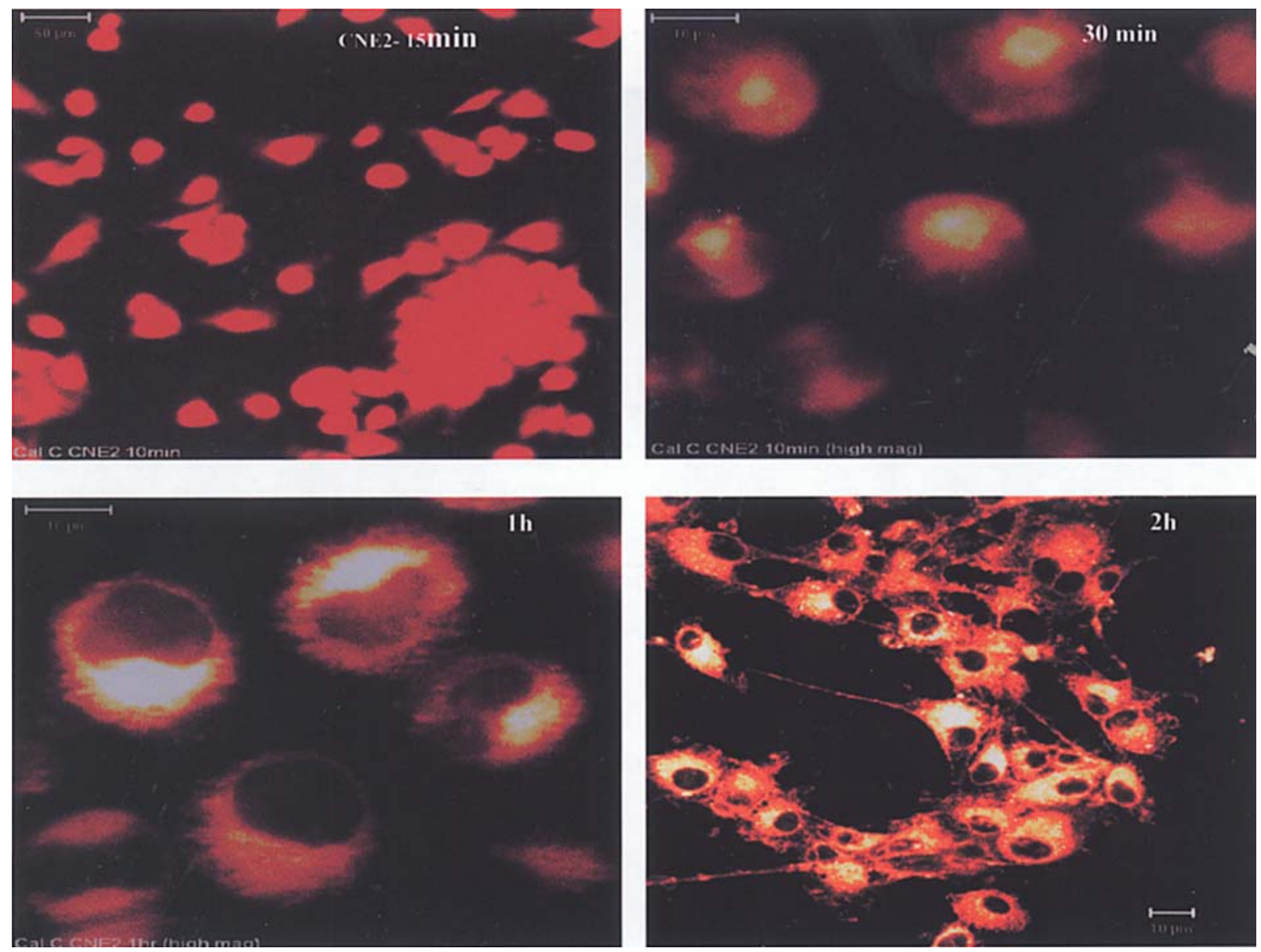

Figure 3. The intracellular distribution of Cal C $(150 \mathrm{nM})$ was studied in representative NPC-CNE2 cells. Confocal images reveal the cellular distribution of $\mathrm{Cal} \mathrm{C}$ at indicated time points.

indirectly for caspase-specific cleavage of poly (ADP-ribose) polymerase (PARP). The induction of apoptosis was further monitored by demonstrating DNA fragmentation at $4 \mathrm{~h}$ post irradiation as the appearance of the sub-G1 peak in cell cycle analysis and by TUNEL (TdT-mediated dUTP nick and labeling) assay. The phosphatidylserine exposure at the external surface of the cell was performed by the binding of FITC-labeled annexin V using the ApoAlert annexin V apoptosis kit (Clontech, USA). The flow cytometric assay of apoptosis was confirmed by transmission electron microscopy (TEM) showing the typical morphology of apoptotic cells.

Statistical analysis. Statistical analysis was performed using SigmaStat software. Results were expressed as mean \pm SEM of at least 3 independent experiments. Student's t-test (Paired t-test) was applied to test significant differences between control (drug-treated non-irradiated) and light irradiated groups and a p-value of $<0.05$ was considered to indicate statistical significance. For flow cytometry experiments, histogram of 1 out of 3 experiments (with representative concentration) was plotted and data expressed as means.

\section{Results}

We performed some initial experiments to evaluate the light activation requirements of $\mathrm{Cal} \mathrm{C}$ (Fig. 1) to determine its pharmacokinetics (Fig. 2), uptake efficiency (Fig. 3) and drug concentration dependence on phototoxicity. Cell viability (Fig. 4) was determined by the crystal fast violet assay $(18,24)$. In the absence of light, $\mathrm{Cal} \mathrm{C}$ did not demonstrate a cytotoxic effect on any of the cell lines tested. Increasing the drug concentration resulted in a concomitant decrease in cell viability. Eighty percent loss in cell viability was demonstrated with $37.5 \mathrm{~nm}$ of Cal $\mathrm{C}$ and significant cell death was seen with drug concentration as low as $10 \mathrm{nM}$ (data not shown). We did not observe any significant difference in sensitivity and phototoxicity between the various cell lines studied.

Treatment with Cal C caused apoptosis in NPC and other types of tumor cells in a drug dose-dependent fashion as determined by standard apoptosis assays. TUNEL assay allowed the detection of exposed 3'-hydroxyl groups in fragmented DNA, whereas cell cycle analysis allowed the DNA content analysis in the sub-G1 phase using propidium iodide (Fig. 5A and B). $\mathrm{Cal} \mathrm{C}$ treated photosensitized cells exhibited increasing caspase-3 activity as shown by spectrofluorimetry (Fig. 6A). This was further confirmed with flow cytometry using anticaspase-3 antibody (Fig. 6B) and indirectly by Western blot analysis for PARP cleavage (Fig. 6C). Caspase-3 activation was again confirmed by inhibiting its activity using both specific (DEVD) and broad spectrum (z-VAD) caspase inhibitors (Fig. 6D). Furthermore, PS externalization was shown using flow cytometry (Fig. 7). 


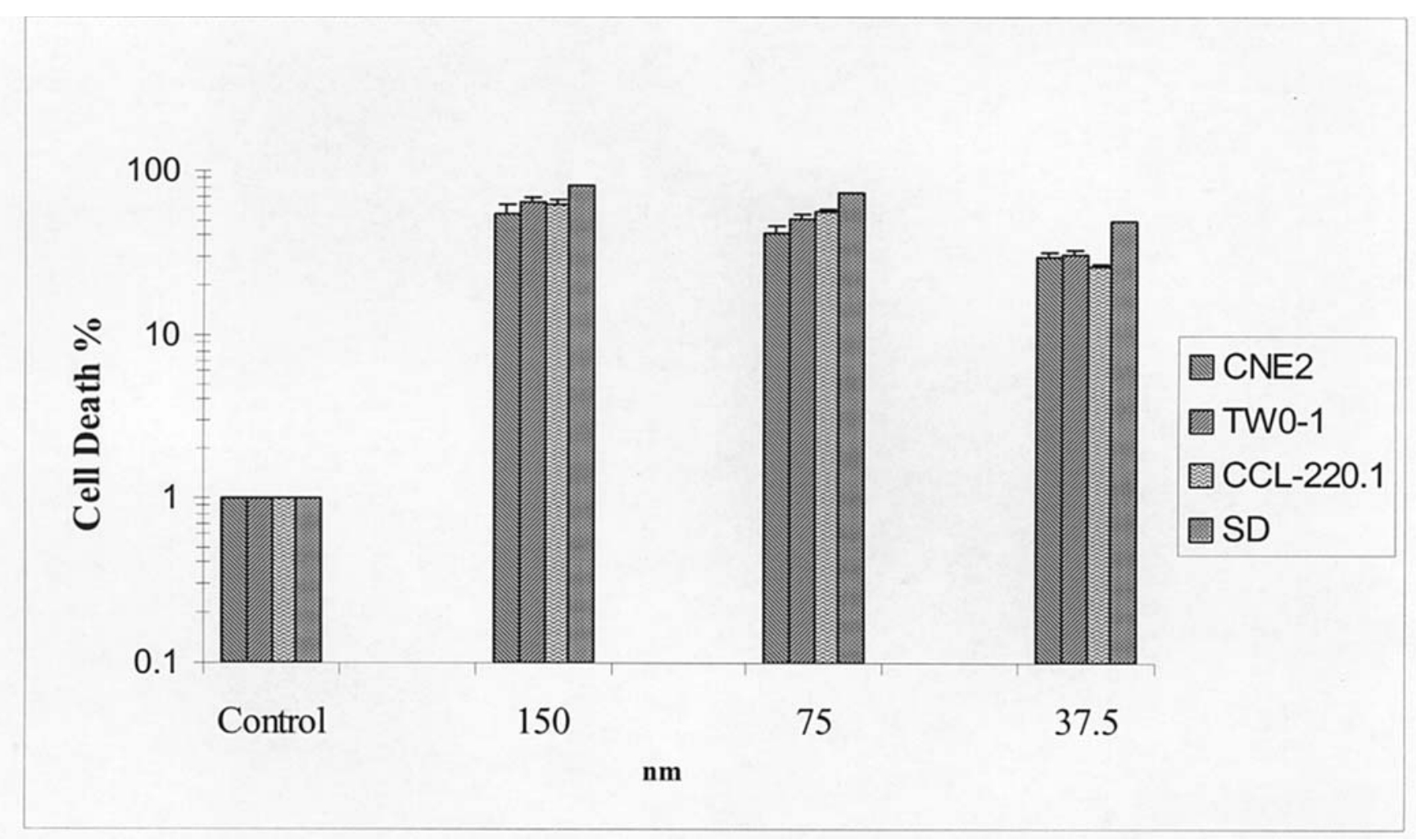

Figure 4. Cell viability of CNE2, TW0-1, CCL-220.1 and SD cells with Cal C was studied. Cells $\left(1 \times 10^{6} / \mathrm{ml}\right)$ were treated with respective concentrations $(37.5-150 \mathrm{nM})$ for $2 \mathrm{~h}$. At $18 \mathrm{~h}$ following irradiation, cells were subjected to crystal fast violet assay. Data shown are representative of at least 3 separate experiments.

Biochemical findings were further supported by morphologic findings using light microscopy. A representative image (Fig. 8) from CNE2, a nasopharyngeal cancer cell line demonstrates that cells treated with higher concentration of $\mathrm{Cal} \mathrm{C}$ without light exposure had normal nuclear and cytoplasmic appearance. In contrast, photo-irradiated cells exhibited classic characteristic features of apoptosis such as cell shrinkage, nuclear condensation, membrane blebbing, and membrane-bound apoptotic bodies. These morphologic features were also confirmed by transmission electron microscopy (TEM) (data not shown) in the photosensitized cells in vitro. Since our previous studies demonstrated Fas/FasL expression in head and neck, bladder and colon cells by hypocrellins and hypericin, we investigated whether the same phenomena would occur also in Cal $\mathrm{C}$ photosensitized cells. Indeed, our results shown in Fig. 9A and B demonstrate the Fas/FasL expression in cell lines used in this study. Immunocytochemistry confirmed the above results of Fas/FasL expression in the irradiated cells (data not shown). In line with the above, the present study further demonstrates the induction of initiator caspase-8 activity (Fig. 10), and a drop in mitochondrial transmembrane potential (Fig. 11), highlighting the efficiency of $\mathrm{Cal} \mathrm{C}$ for the induction of apoptosis.

\section{Discussion}

Although the photodynamic activity of $\mathrm{Cal} \mathrm{C}$ has been known for more than 5 decades (25), the present study describes the fortuitous rediscovery of its photodynamic efficiency in inducing apoptosis in cancer cells. Our pharmacokinetics and biodistribution data support the relationship between the biodistribution of $\mathrm{Cal} \mathrm{C}$ and its observed photodynamic effects as seen with other photosensitizers (26). It is known that the therapeutic effect of PDT is due to cellular cytotoxicity. Also that Cal C can induce cell death via apoptosis in heart smooth muscle cells similarly to other PKC inhibitors $(13,14,18,27,28)$. Hence, our study demonstrates that Cal C-PDT can also induce apoptosis in nasopharyngeal (CNE2 and TWO-1), colon (CCL-2) and bladder (SD) cancer cells but in a death receptordependent fashion.

Death can be signalled directly, either as a result of cell injury or through cytokine-mediated pathways (29). Recent investigations have clearly established that certain receptorligand interactions selectively initiate cell death (30). Two members of the tumor necrosis factor (TNF) family of cell surface signalling molecules, Fas/APO-1/CD95 and TNFR-1, are potent inducers of apoptosis upon stimulation by their respective ligands, the cytokines Fas ligand (FasL). These (Fas/FasL system) could either signal the apoptotic death directly through the activation of the caspase system or through mitochondria by releasing mitochondrial proteins or sometimes, through activation of sphingomyelinase, releasing ceramide and phosphocholine from sphingomyelin (ceramide pathways) $(29,31,32)$.

Many elegant studies have highlighted the role of Fas/FasL system in PDT induced apoptosis $(28,33,34)$. It is known that the Fas antigen is trimerized upon activation transducing 
A
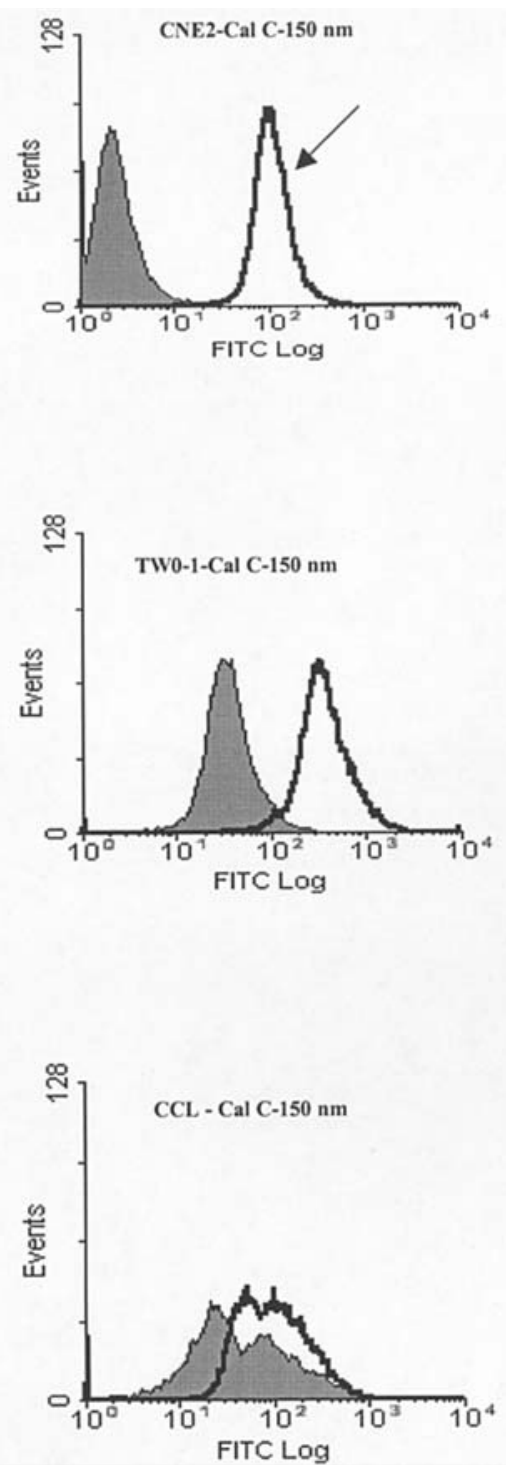
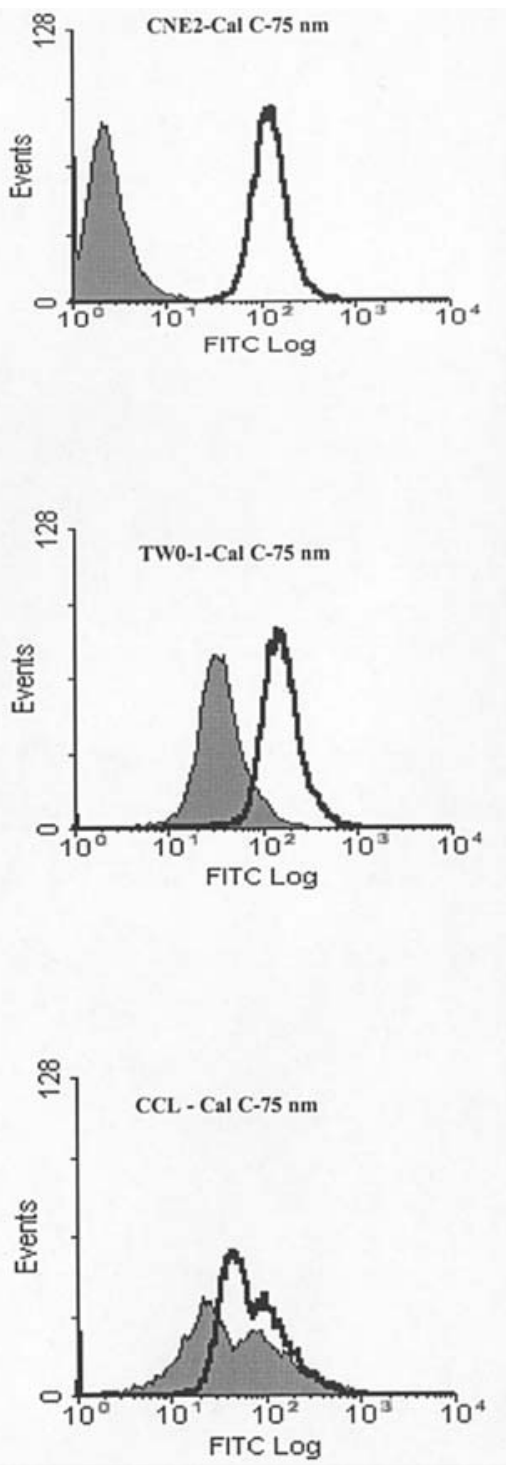

B

Control

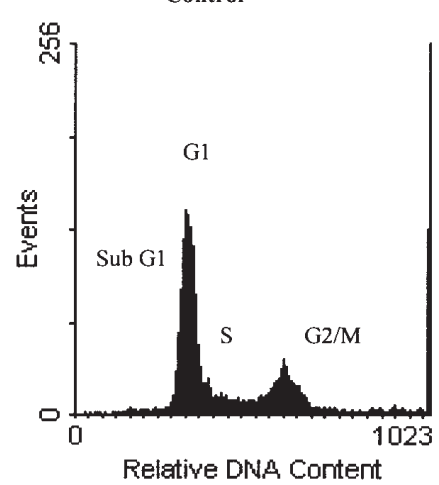

CNE2-Cal C-75 nm

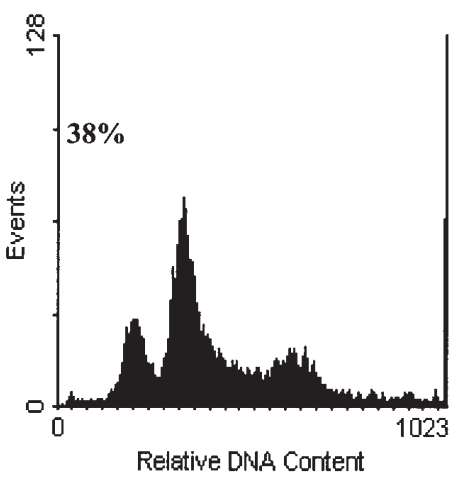

CNE2-Cal C-150 nm

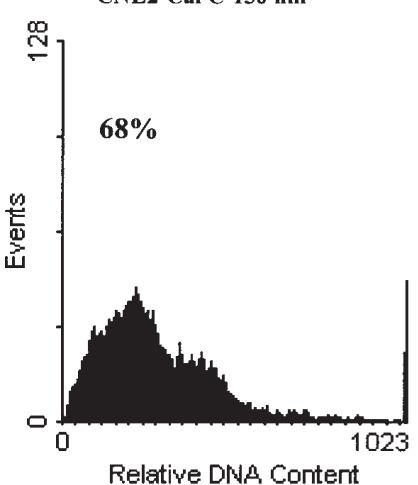

Figure 5. (A) Flow cytometric detection of apoptosis by annexin-V assay in NPC and colon cells. The left shaded histogram represents Cal C-treated, nonirradiated control cells, and the right solid lines indicate Cal C-treated irradiated cells. (B) Analysis of DNA cleavage in Cal C-PDT induced apoptotic cells. Cal C-PDT results in the appearance of a sub-G1 population (sub-diploid DNA) indicating DNA fragmentation. Data shown are the mean of 3 independent experiments.

a death signal to FADD $(35,36)$ and activates a series of intracellular events, which leads to a death cascade composed of intracellular caspases of up and downstream events. Since our previous studies $(20,37)$ have demonstrated the induction of Fas/FasL in NPC (CNE2, TWO-1) and other cell lines such as colon (CCL-2) and bladder (SD) by hypocrellins and 
A

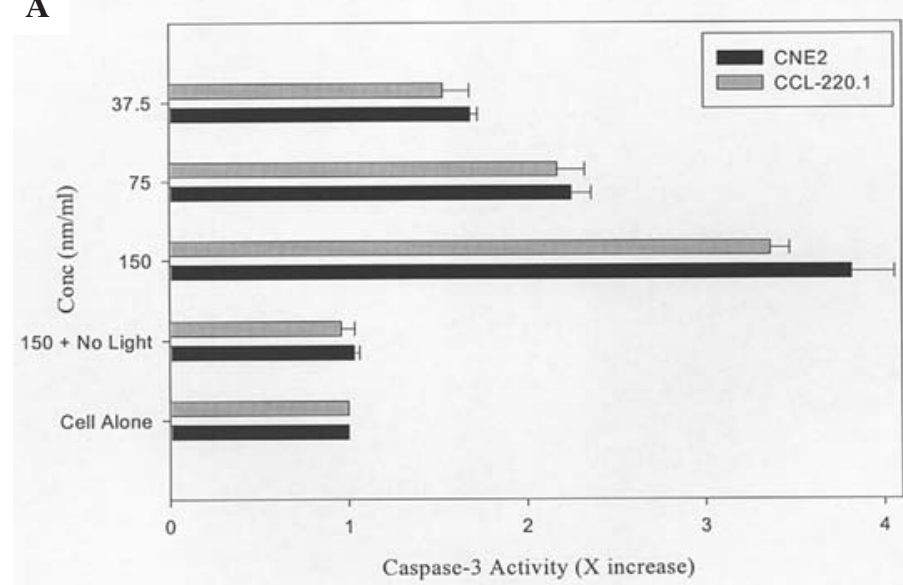

Figure 6. (A) Activation of caspase-3 induced by Cal C-PDT in NPC-CNE2 and colon CCL-2 cells was analyzed by spectrofluorimetry (B), by flow cytometry using anti-active caspase- 3 that recognizes the processed form of caspase- 3 . The shaded histograms are for mouse $\operatorname{IgG} 1 \kappa$ used as an isotype control, the dotted lines represent drug-treated, non-irradiated control cells, and the solid lines indicate $\mathrm{Cal} \mathrm{C}$-treated irradiated cells. (C) Indirect assessment of caspase-3 activity by Western blotting. The intact protein 116 $\mathrm{kDa}$ and the proteolytic fragment of $85 \mathrm{kDa}$ was marked and (D) the inhibition of caspase-3 activity was shown in NPC-CNE2 by pre-treating $100 \mu \mathrm{M}$ DEVD-CHO or z-VAD-fmk.

B
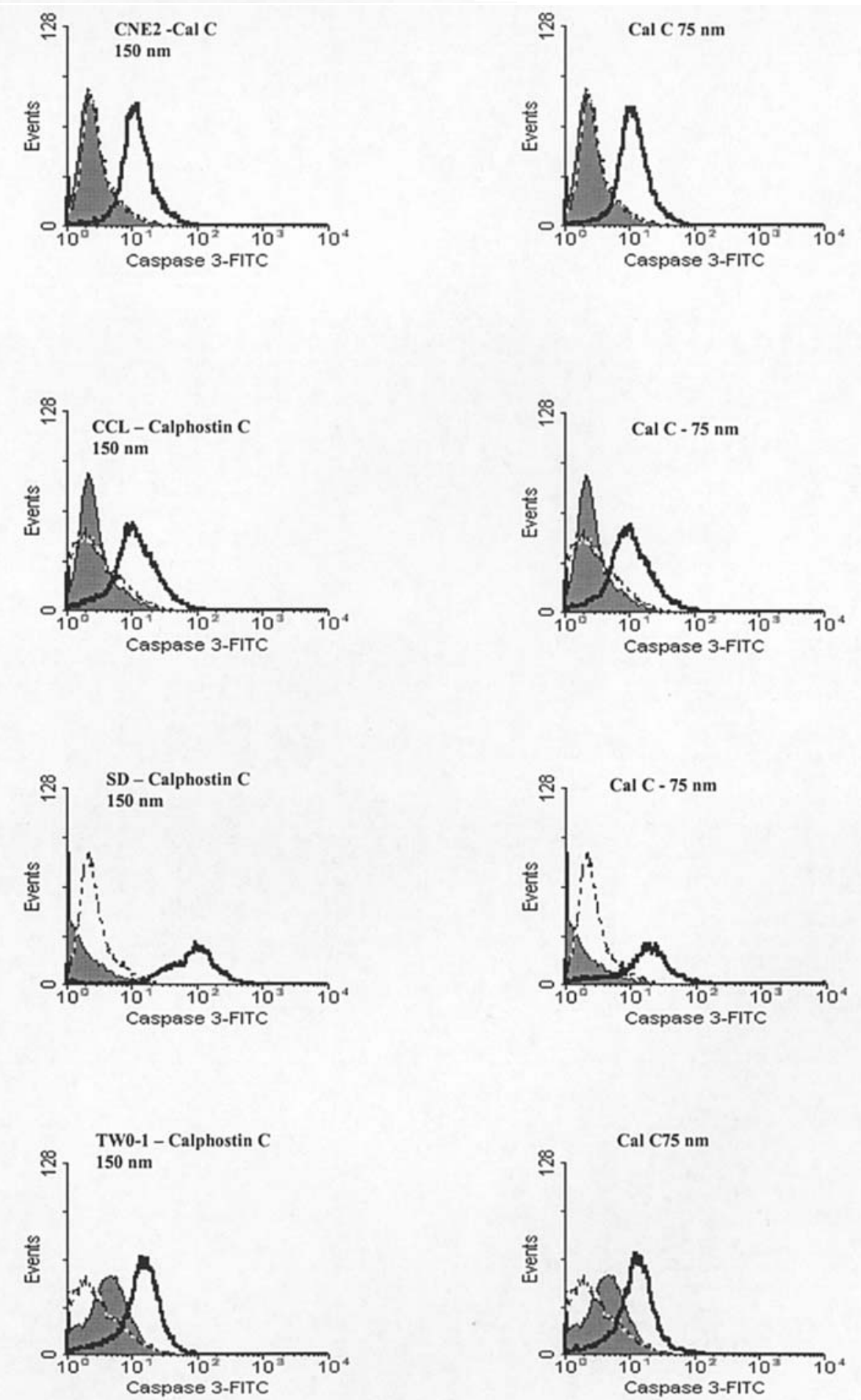
C

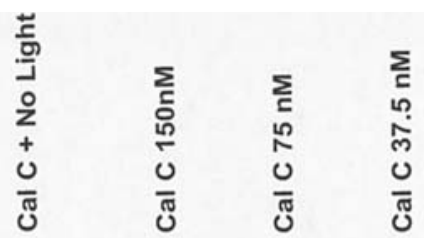

CNE2

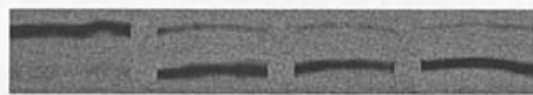

$116 \mathrm{KD}$

$85 \mathrm{KD}$

TWO-2
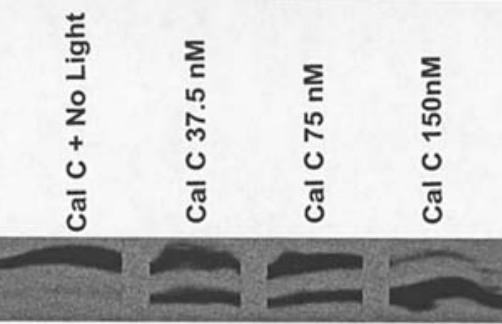

$116 \mathrm{KD}$

$85 \mathrm{KD}$

CCL-2

D

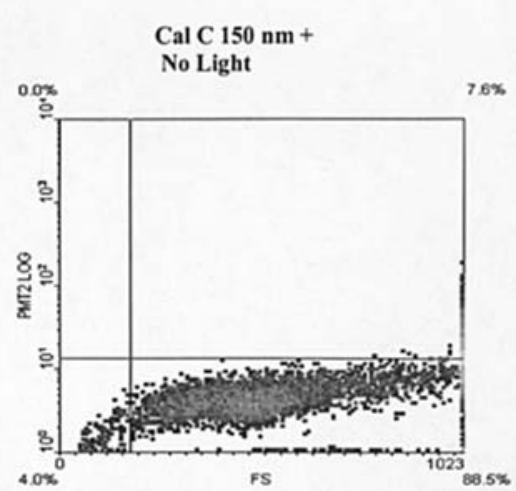

Cal C $150 \mathrm{~nm}$
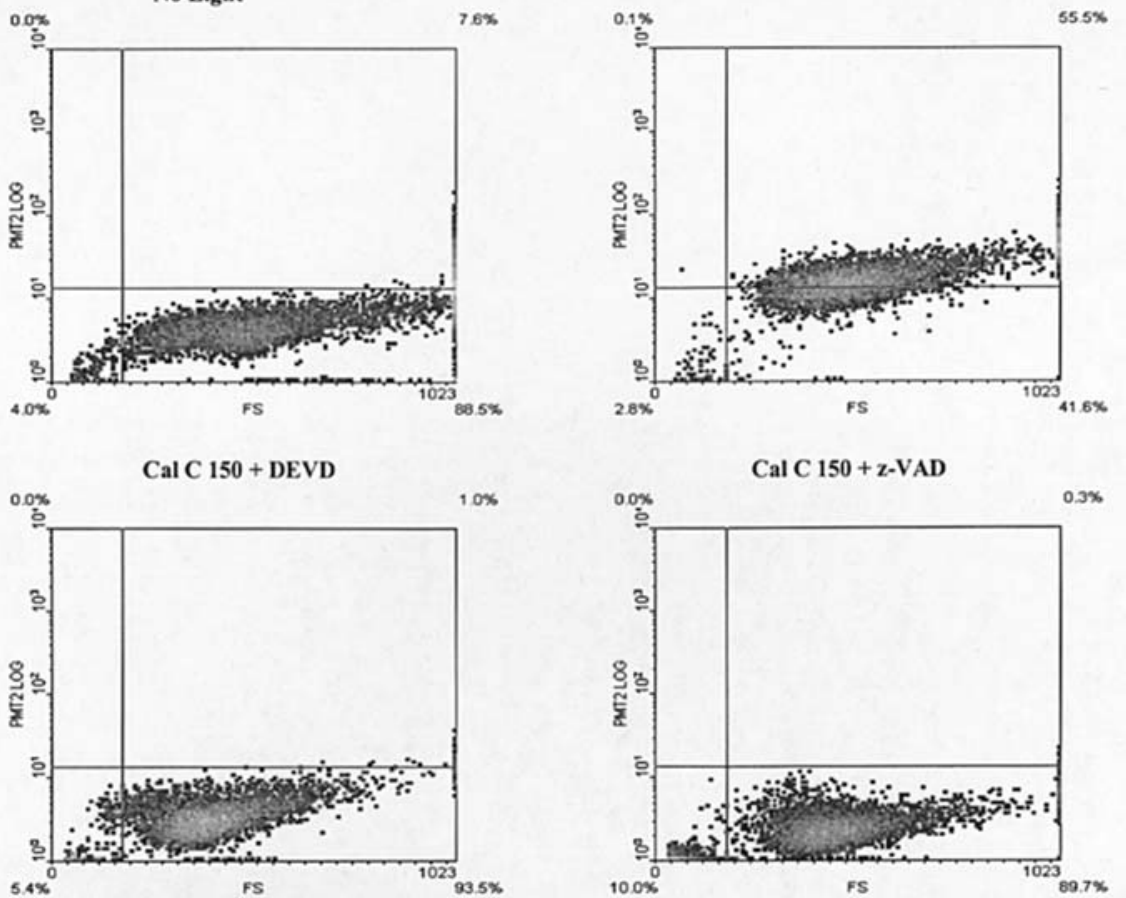

$\begin{array}{lc}5.4 \times & \text { FS } \\ \text { Cal C } 150 \mathrm{~nm}+\end{array}$

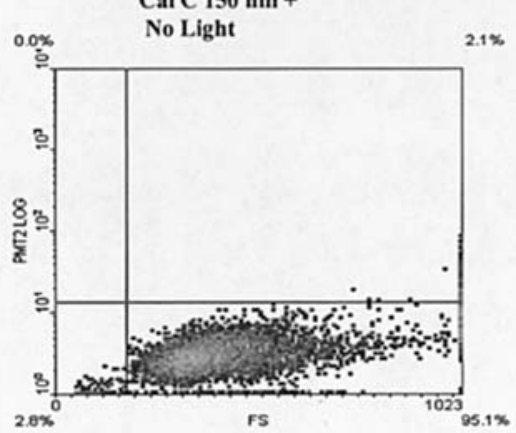

$10.0 \%$

Cal C $150 \mathrm{~nm}$
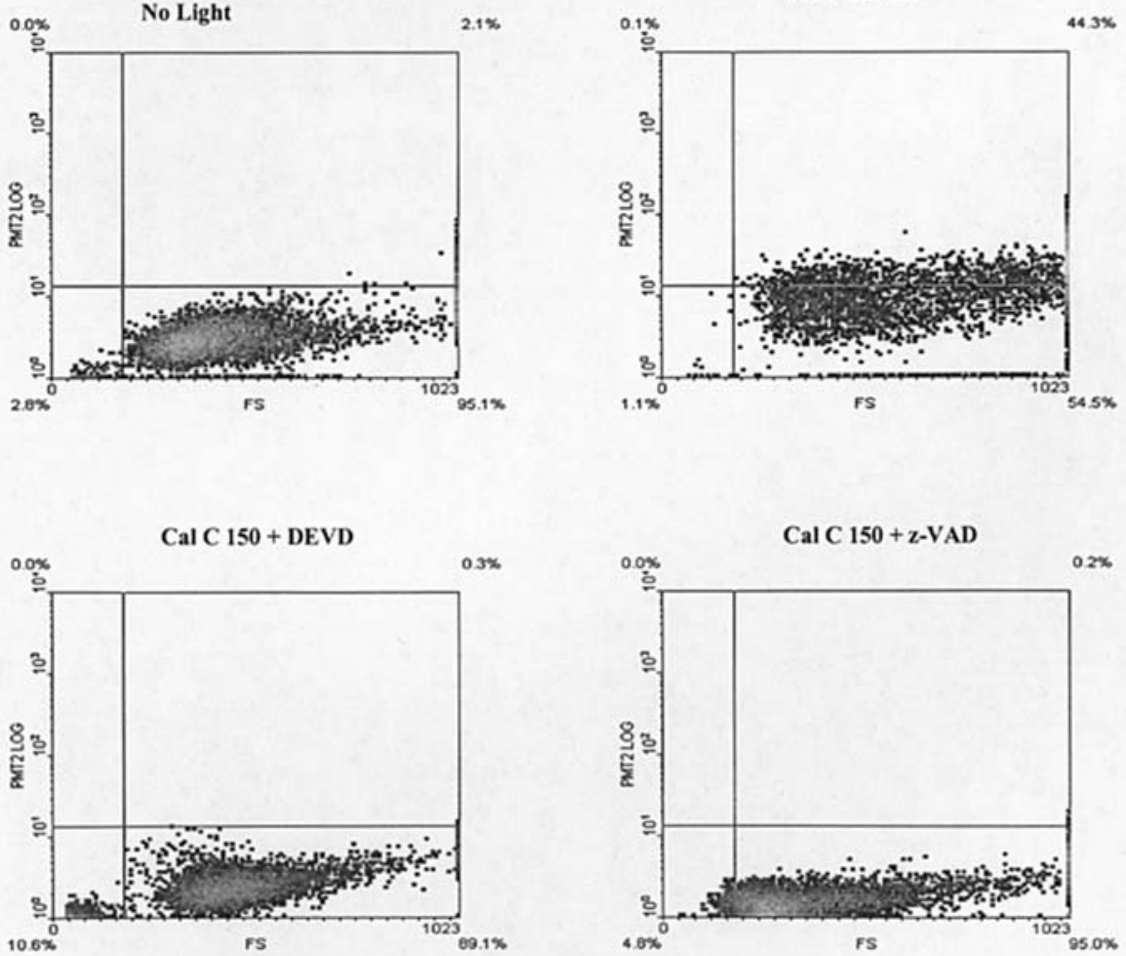

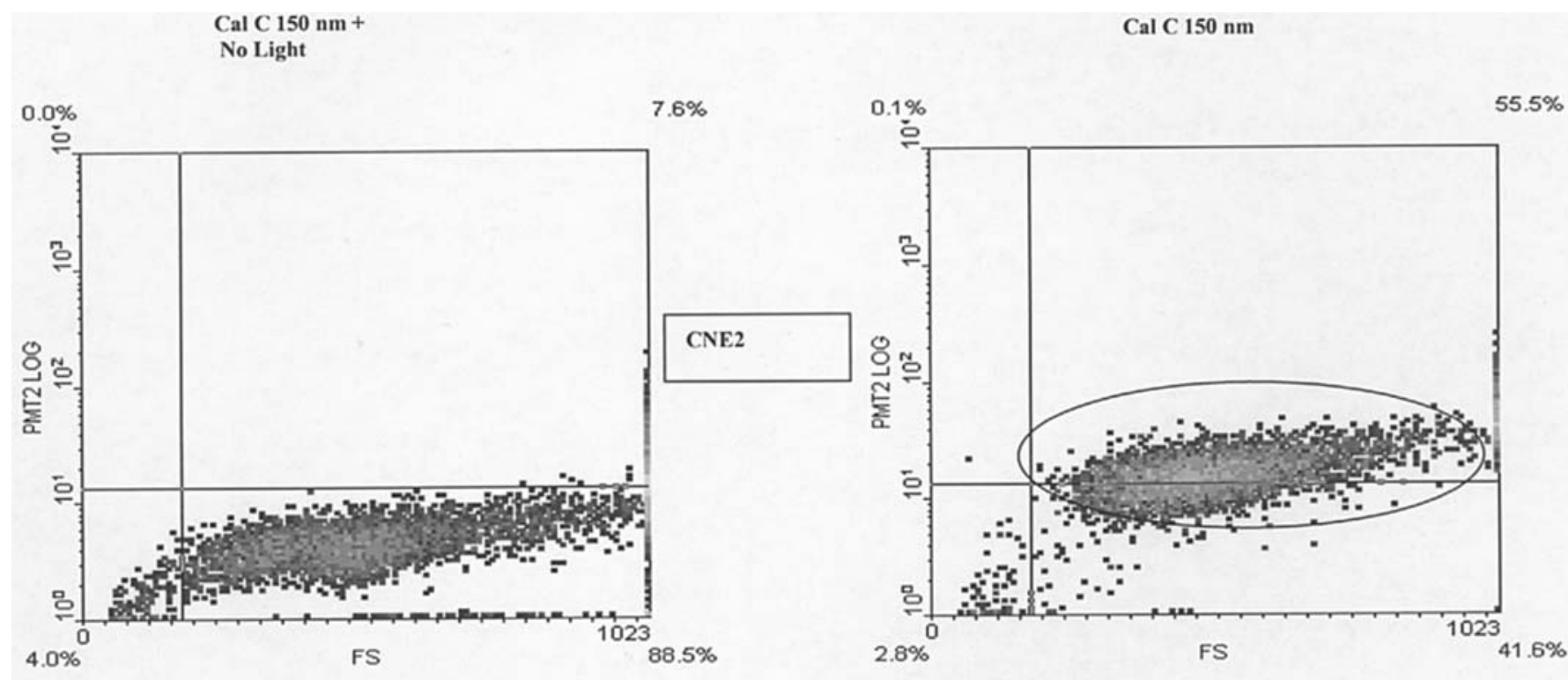

Figure 7. Phosphatidylserine (PS) externalization induced by Cal C-PDT was demonstrated in NPC-CNE2 cells. Control and irradiated cells were stained with Annexin-FITC and subjected for flow cytometry. The boxed area in the dot blot indicates FITC-positive PS-overexpressing cells as compared to drug-treated non-irradiated control cells.
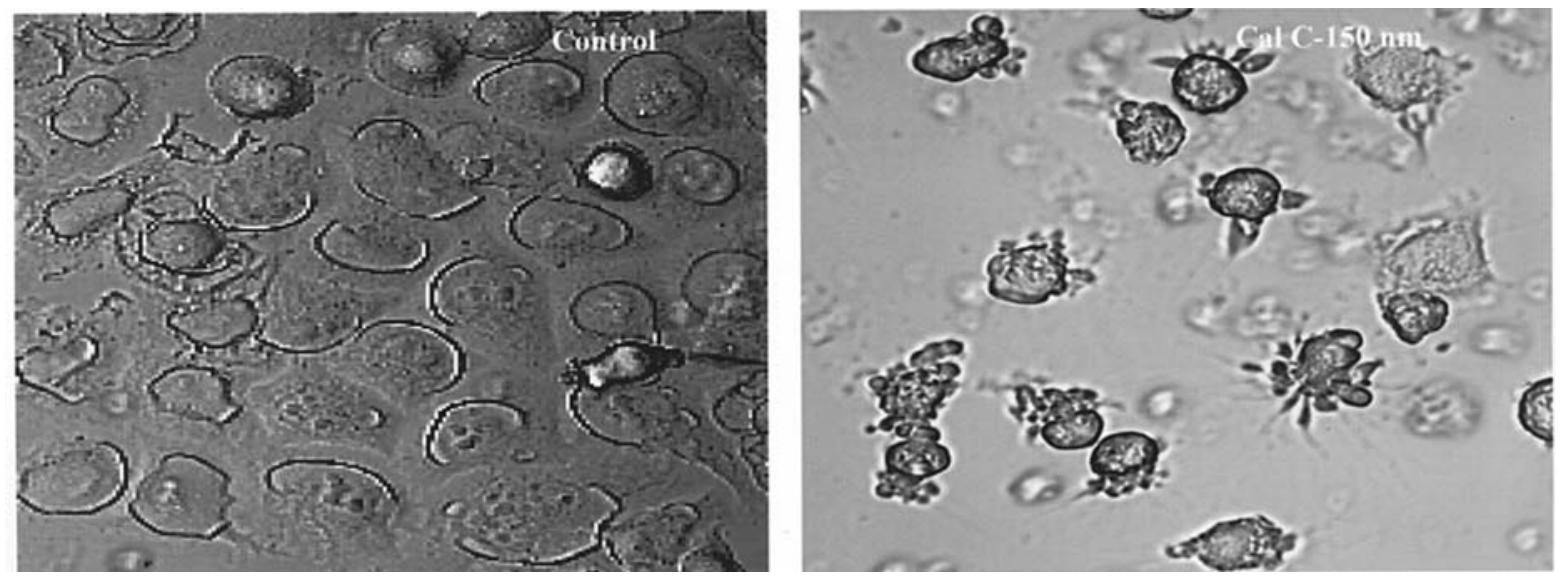

Figure 8. Phase micrograph showing typical apoptotic features such as intact cell membrane, but shrinkage in cell size and membrane blebbing as a result of Cal C-PDT.

hypericin-PDT, we reasoned that Cal C-PDT may also induce Fas/FasL expression in these as Cal $\mathrm{C}$ also exerted its photodynamic efficiency by inducing early apoptosis by 1-3 $\mathrm{h}$ following irradiation. Our flow cytometry results confirmed the expression of Fas/FasL in NPC and colon cancer cells but not in SD cells. It will be a subject of investigation in future why the bladder cells are not expressing Fas/FasL following $\mathrm{Cal}$ C-PDT and what could be the other mechanism involved in these cells.

Apoptosis is induced by sequential activation of caspases (38). In order to evaluate the involvement of caspases in $\mathrm{Cal}$ C-PDT-induced apoptosis, we examined the activities of caspases by various direct and indirect approaches including pretreating cells with caspase inhibitors. Our study revealed the activation of the caspase cascade, caspase- 8 and -3 , following direct activation of Fas/FasL in Cal C-PDT-induced apoptosis in NPC and colon cells. The activation of caspase- 8 and -3 following Cal C-PDT was significantly increased and pretreatment of the cells with caspase-3-specific inhibitor DEVD and broad-spectrum caspases inhibitor z-VAD significantly suppressed the activity of caspase- 3 and IETD inhibited caspase- 8 activity, suggesting the sequential activation of caspase-8/-3 cascades in Cal C-PDT-in NPC and other cells.

The PDT-induced apoptosis is supposed to be mediated through mitochondria $(39,40)$, which releases at least two soluble proteins, cytochrome c and AIF, during apoptosis. These molecules released into the cytosol initiate apoptotic signal events (41), activating caspase- 9 and then caspase- 6 and -7 , respectively (42). The present study demonstrates the drop in mitochondrial potential and cytosolic release of cytochrome c (data not shown) within $2 \mathrm{~h}$ of Cal C-PDT. This was followed by caspase- 8 activation within $1 \mathrm{~h}$, suggesting that cytochrome $\mathrm{c}$ is involved in Cal C-PDT-induced apoptosis. 
A
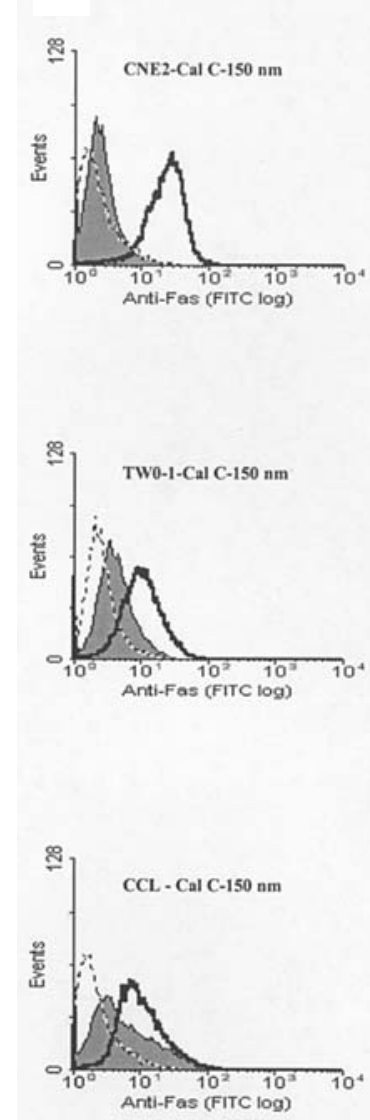
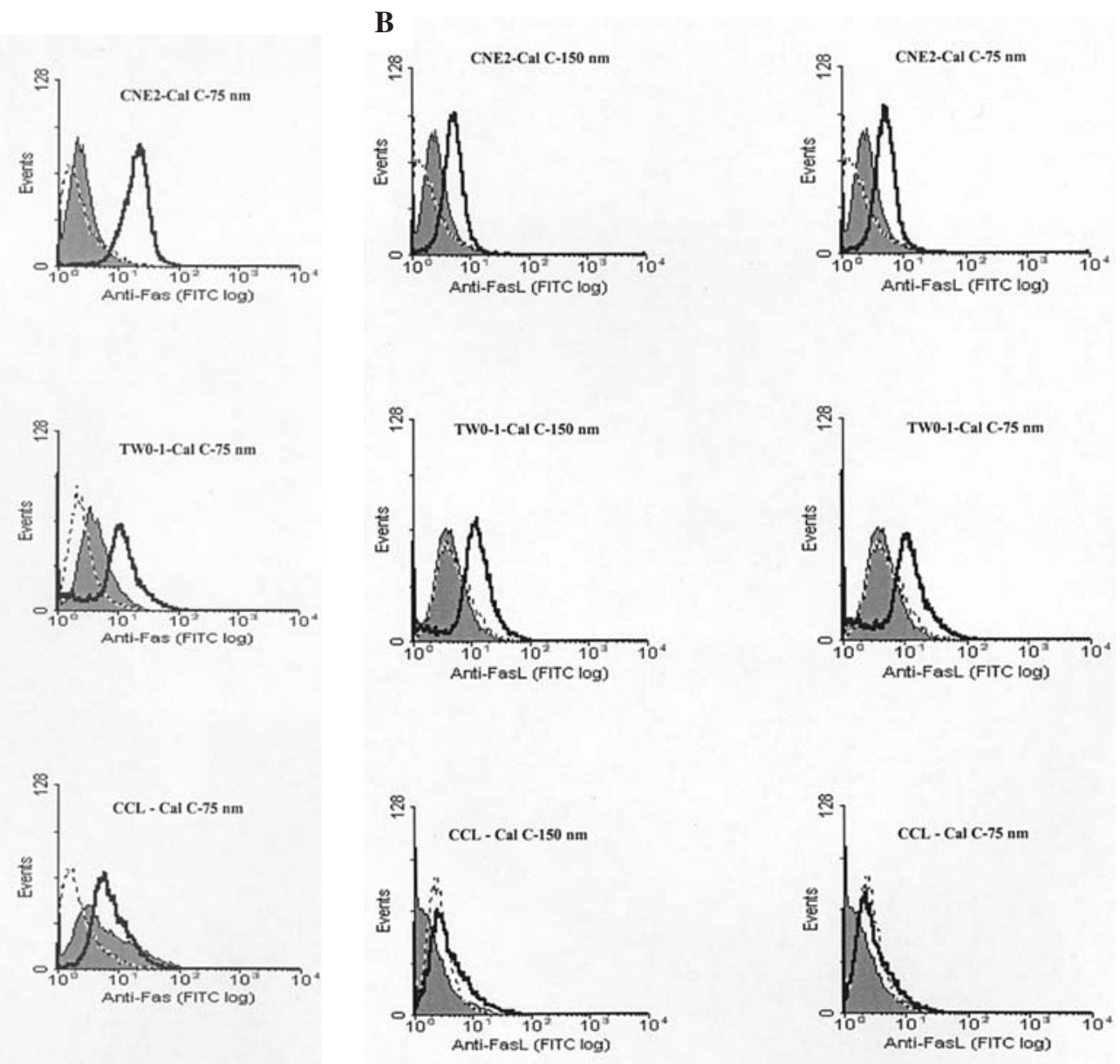

Figure 9. Cal C-PDT induced expression of Fas (A) and FasL (B) in NPC and colon cells. The surface expression of Fas and FasL was analyzed within 2 h

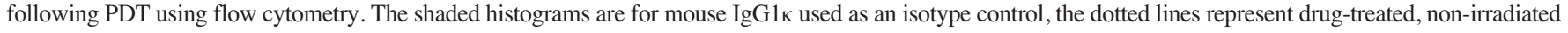
control cells, and the solid lines indicate Cal C-treated irradiated cells. At least 10,000 events were counted, and data shown are representative of at least 3 separate experiments.

Our results may support the hypothesis of mitochondriabased photodynamic anti-cancer therapy (43).

The biological effect of PDT depends on singlet oxygen or other oxygen species induced cell death $(23,44,45)$. Cytochrome $\mathrm{c}$ release is triggered by mitochondrial depolarization following cell injury (41). Mitochondria can be a source of reactive oxygen species (ROS) and a target of oxidative damage during oxidative stress (46). Previous studies have shown that the ROS induce mitochondrial depolarization and release of cytochrome c during phthalocyanine 4 and hypericin-PDT $(23,40)$. Our results demonstrate a reduction in mitochondrial potential in Cal C-treated cancer cells, suggesting that Cal C-PDT may also produce ROS which are critical to the induction of apoptosis, which may induce mitochondrial depolarization and release cytochrome $\mathrm{c}$. The type of ROS produced after Cal C-PDT is yet to be addressed.

In conclusion, we have shown that Cal C-PDT induced apoptosis of NPC, colon and bladder cells, which is mediated by activation of a distinct caspase cascade, specifically 8 and 3 . Furthermore, Cal C-PDT induced activation of Fas with the involvement of the Fas ligand system and reduction in mitochondrial potential in NPC and colon cancer cells. Our results demonstrate that the inducer of apoptosis by the activation of caspases and Fas/FasL during Cal C-PDT, might be applicable for the treatment of various cancers.

\section{Acknowledgements}

We wish to thank National Medical Research Council of Singapore and National Cancer Centre for their funding and facilitating this study and Ms. Vanaja Manivasager for editorial assistance.

\section{References}

1. Dougherty TJ, Gomer CJ, Henderson BW, Jori G, Kessel D, Korbelik M, Moan J and Peng Q: Photodynamic therapy. J Natl Cancer Inst 90: 889-905, 1998.

2. Krammer B: Vascular effects of photodynamic therapy. Anticancer Res 21: 4271-4277, 2001.

3. Almeida RD, Manadas BJ, Carvalho AP and Duarte CB: Intracellular signaling mechanisms in photodynamic therapy. Biochim Biophys Acta 1704: 59-86, 2004.

4. Du HY, Bay BH and Olivo M: Biodistribution and photodynamic therapy with hypericin in a human NPC murine tumor model. Int J Oncol 22: 1019-1024, 2003.

5. Krieg RC, Messmann H, Schlottmann K, Endlicher E, Seeger S, Scholmerich $\mathrm{J}$ and Knuechel R: Intracellular localization is a cofactor for the phototoxicity of protoporphyrin IX in the gastrointestinal tract: in vitro study. Photochem Photobiol 78: 393-399, 2003. 


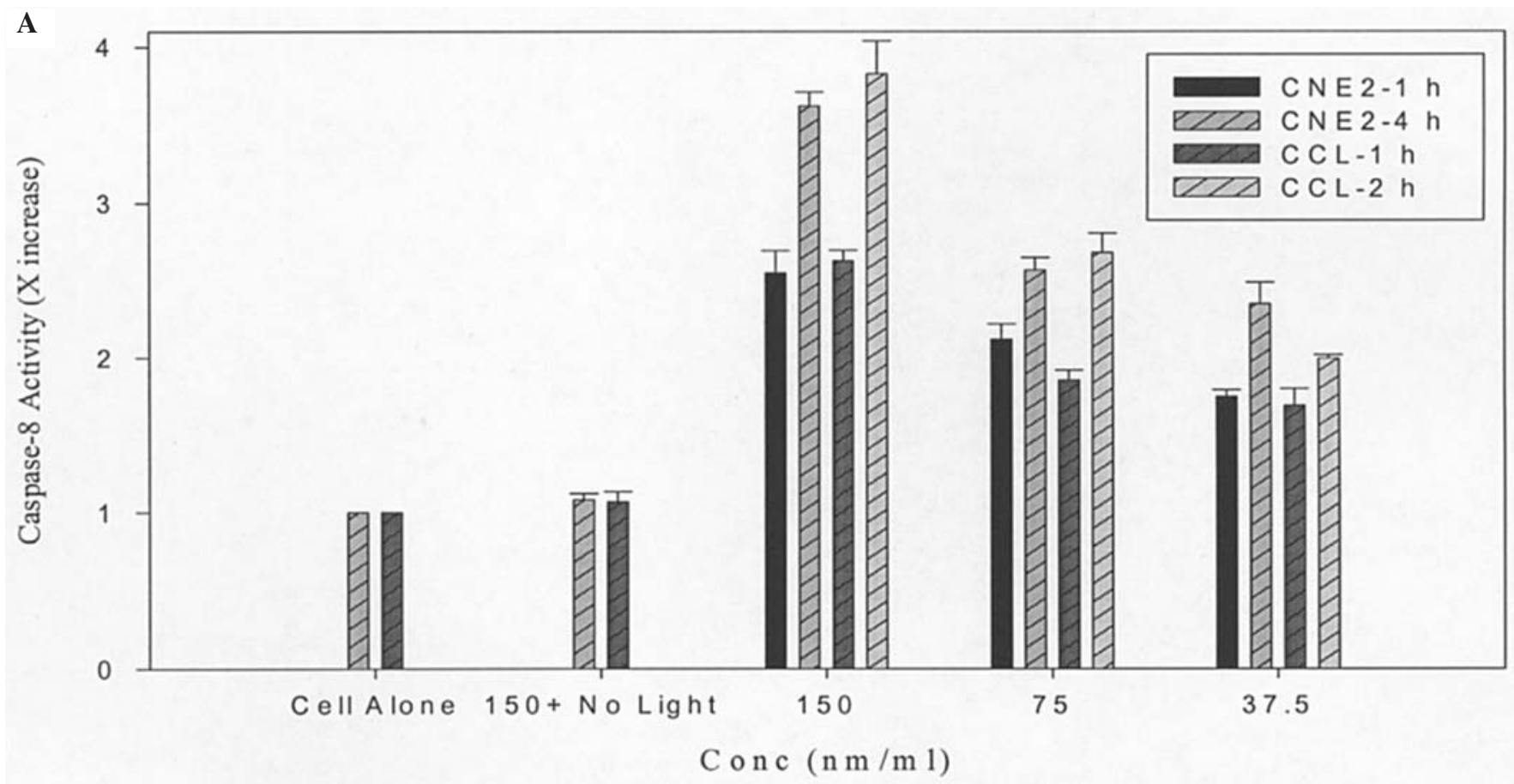

$\mathbf{B}$

Light alone
A
B
C
D
E
F
G $\quad \mathrm{H}$

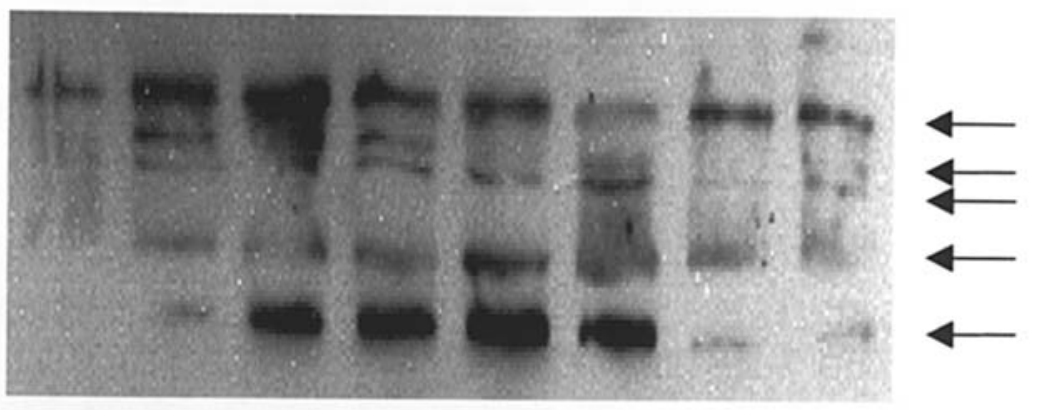

55 kD

$43 \mathrm{kD}$

$41 \mathrm{kD}$

$23 \mathrm{kD}$

$18 \mathrm{kD}$

\section{A - Drug; B - CNE2 -Cal C-150 nm; C - TW0-1, Cal C-150; D - CCL-220.1, Cal C-150 nm; E - SD Cal C-150; F - CNE2 Cal C-150 + IETD; G - CNE2 Cal C-150 + IETD; H - CCL-220.1 Cal C-150 + IETD}

Figure 10. Activation of caspase-8 (FLICE) induced by Cal C-PDT in NPC (CNE2) and colon (CCL-2) cells. (A). Caspase-8 analysis was done by the fluorimetric assay method. At 1-2 h post PDT in lysates of CNE2 and CCL-2 cells. To inhibit caspases-8 enzyme activity, a caspase-8-specific inhibitor, IETD-FMK $(100 \mu \mathrm{M} / \mathrm{ml})$, was added to the samples prior to the addition of the substrate. Data are the mean $\pm \mathrm{SE}$ of 3 independent experiments and are shown as the fold increase in relative fluorescence units (x RFU). (B) CNE2, TWO-1, CCL-1 and SD cell lysates were subjected for SDS-PAGE analysis. Membrane was blotted with primary antibody against caspase- 8 followed by ECL to show the activation of caspase- 8 . Note the arrow highlights the products and the activity was inhibited by caspase-8-specific inhibitor IETD.

6. Fabris C, Valduga G, Miotto G, Borsetto L, Jori G, Garbisa S and Reddi E: Photosensitization with zinc (II) phthalocyanine as a switch in the decision between apoptosis and necrosis. Cancer Res 61: 7495-7500, 2001.

7. Ali SM, Chee SK, Yuen GY and Olivo M: Hypericin and hypocrellin induced apoptosis in human mucosal carcinoma cells. J Photochem Photobiol B 65: 59-73, 2001.

8. Kobayashi E, Ando K, Nakano H, Iida T, Ohno H, Morimoto M and Tamaoki T: Calphostins (UCN-1028), novel and specific inhibitors of protein kinase C. I. Fermentation, isolation, physicochemical properties and biological activities. J Antibiot (Tokyo) 42: 1470-1474, 1989.
9. Diwu Z and Lown JW: Photosensitization with anticancer agents 15. Perylenequinonoid pigments as potential photodynamic therapeutic agents: formation of semiquinone radicals and reactive oxygen species on illumination. J Photochem Photobiol B 18: 131-143, 1993 .

10. Diwu Z and Lown JW: Photosensitization with anticancer agents 19. EPR studies of photodynamic action of calphostin C: formation of semiquinone radical and activated oxygen on illumination with visible light. Free Radic Biol Med 16: 645-652, 1994.

11. Hudson JB, Imperial V, Haugland RP and Diwu Z: Antiviral activities of photoactive perylenequinones. Photochem Photobiol 65: 352-354, 1997. 

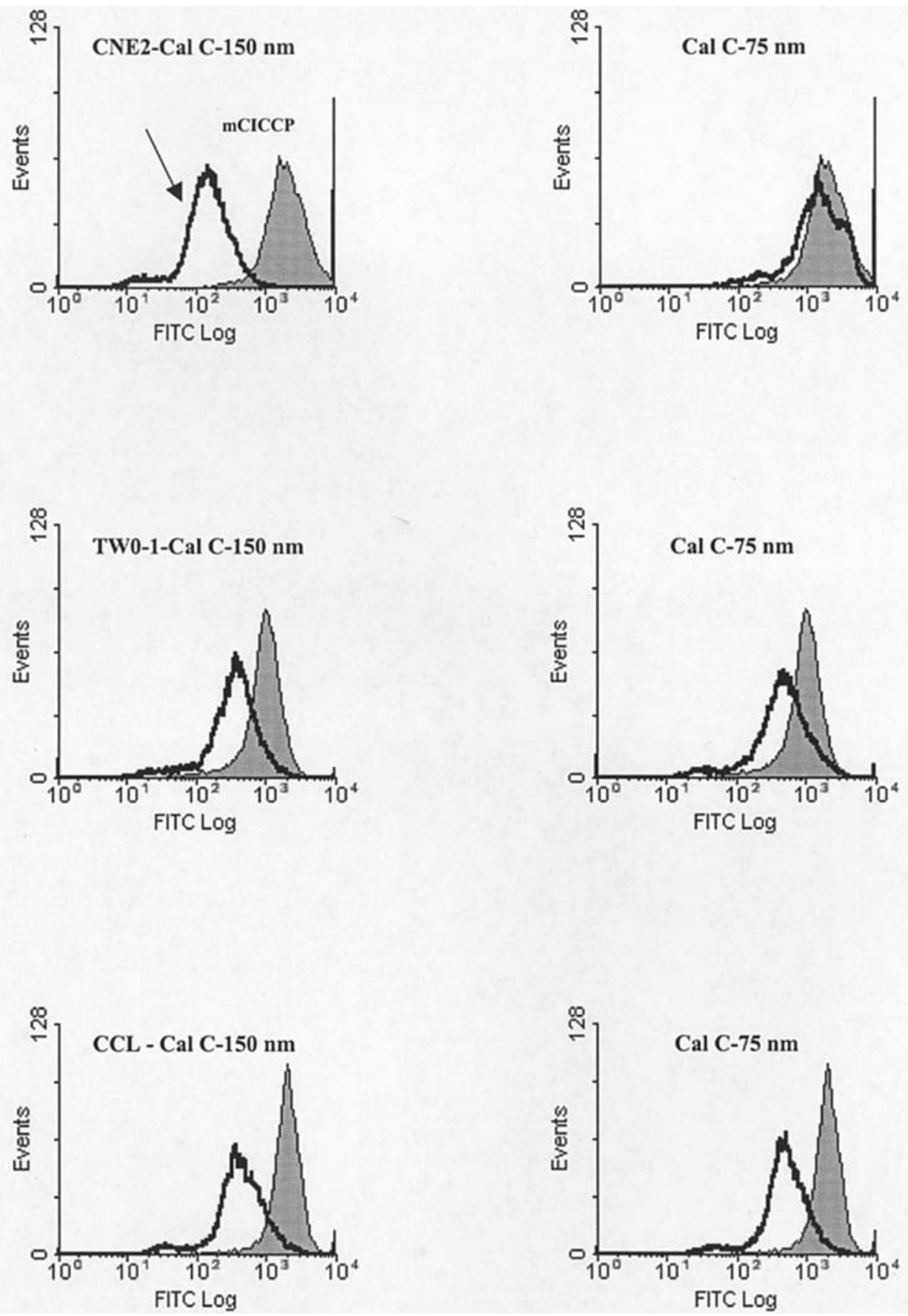

Figure 11. Cal C-PDT triggered drop in mitochondrial membrane potential $(\Delta \Psi \mathrm{m})$, the event dependent on MPT pore. Cal C-treated irradiated NPC (CNE2 and TW0-1) and colon (CCL-2) cells were stained with membrane potential-sensitive probe DiOC6 (40 nmol/1) for $30 \mathrm{~min}$ at $37^{\circ} \mathrm{C}$ and analyzed by flow cytometry. A known probe (mCICCP), which induces membrane potential reduction was used as a control.

12. Kobayashi E, Nakano H, Morimoto M and Tamaoki T: Calphostin C (UCN-1028C), a novel microbial compound, is a highly potent and specific inhibitor of protein kinase C. Biochem Biophys Res Commun 159: 548-553, 1989.

13. Weller M, Trepel M, Grimmel C, Schabet M, Bremen D, Krajewski S and Reed JC: Hypericin-induced apoptosis of human malignant glioma cells is light-dependent, independent of bcl-2 expression, and does not require wild-type p53. Neurol Res 19: 459-470, 1997.

14. Bruns RF, Miller FD, Merriman RL, Howbert JJ, Heath WF, Kobayashi E, Takahashi I, Tamaoki T and Nakano H: Inhibition of protein kinase $\mathrm{C}$ by calphostin $\mathrm{C}$ is light-dependent. Biochem Biophys Res Commun 176: 288-293, 1991.

15. Diwu Z and Lown JW: Phototherapeutic potential of alternative photosensitizers to porphyrins. Pharmacol Ther 63: 1-35, 1994.
16. Guo B, Hembruff SL, Villeneuve DJ, Kirwan AF and Parissenti AM: Potent killing of paclitaxel- and doxorubicinresistant breast cancer cells by calphostin $\mathrm{C}$ accompanied by cytoplasmic vacuolization. Breast Cancer Res Treat 82: 125-141, 2003

17. Kamuhabwa AR, Agostinis PM, D'Hallewin MA, Baert L and de Witte PA: Cellular photodestruction induced by hypericin in AY-27 rat bladder carcinoma cells. Photochem Photobiol 74: 126-132, 2001.

18. Ali SM and Olivo M: Bio-distribution and subcellular localization of Hypericin and its role in PDT induced apoptosis in cancer cells. Int J Oncol 21: 531-540, 2002

19. Chin W, Lau W, Cheng C and Olivo M: Evaluation of Hypocrellin B in a human bladder tumor model in experimental photodynamic therapy: biodistribution, light dose and drug-light interval effects. Int J Oncol 25: 623-629, 2004. 
20. Ali SM, Chee SK, Yuen GY and Olivo M: Photodynamic therapy induced Fas-mediated apoptosis in human carcinoma cells. Int J Mol Med 9: 257-270, 2002.

21. Villunger A, Egle A, Kos M, Hartmann BL, Geley S, Kofler R and Greil R: Drug-induced apoptosis is associated with enhanced Fas (Apo-1/CD95) ligand expression but occurs independently of Fas (Apo-1/CD95) signaling in human T-acute lymphatic leukemia cells. Cancer Res 57: 3331-3334, 1997.

22. Korchak HM, Rich AM, Wilkenfeld C, Rutherford LE and Weissmann G: A carbocyanine dye, DiOC6(3), acts as a mitochondrial probe in human neutrophils. Biochem Biophys Res Commun 108: 1495-1501, 1982.

23. Ali SM, Chee SK, Yuen GY and Olivo M: Hypocrellins and Hypericin induced apoptosis in human tumor cells: A possible role of hydrogen peroxide. Int J Mol Med 9: 461-472, 2002.

24. Mickuviene I, Kirveliene V and Juodka B: Experimental survey of non-clonogenic viability assays for adherent cells in vitro. Toxicol In Vitro 18: 639-648, 2004.

25. Weiss U, Flon $\mathrm{H}$ and Bourger WC: The photodynamic pigment of some species of Elsinoe and Sphaceloma. Arch Biochem Biophys 69: 311-319, 1957.

26. Gupta S, Dwarakanath BS, Muralidhar K and Jain V: Cellular uptake, localization and photodynamic effects of haematoporphyrin derivative in human glioma and squamous carcinoma cell lines. J Photochem Photobiol B 69: 107-120, 2003.

27. Du HY, Olivo M, Tan BK and Bay BH: Photoactivation of hypericin down-regulates glutathione S-transferase activity in nasopharyngeal cancer cells. Cancer Lett 207: 175-181, 2004.

28. Takahashi H, Itoh Y, Miyauchi Y, Nakajima S, Sakata I, Ishida-Yamamoto $\mathrm{A}$ and Iizuka $\mathrm{H}$ : Activation of two caspase cascades, caspase $8 / 3 / 6$ and caspase $9 / 3 / 6$, during photodynamic therapy using a novel photosensitizer, ATX-S10(Na), in normal human keratinocytes. Arch Dermatol Res 295: 242-248, 2003.

29. Wyllie AH: The genetic regulation of apoptosis. Curr Opin Genet Dev 5: 97-104, 1995.

30. O'Brien DI, Nally K, Kelly RG, O'Connor TM, Shanahan F and O'Connell J: Targeting the Fas/Fas ligand pathway in cancer. Expert Opin Ther Targets 9: 1031-1044, 2005.

31. Obeid LM, Linardic CM, Karolak LA and Hannun YA Programmed cell death induced by ceramide. Science 259: 1769-1771, 1993.

32. Rowan S and Fisher DE: Mechanisms of apoptotic cell death. Leukemia 11: 457-465, 1997.

33. Yslas I, Alvarez MG, Marty C, Mori G, Durantini EN and Rivarola V: Expression of Fas antigen and apoptosis caused by $5,10,15,20$-tetra(4-methoxyphenyl)porphyrin (TMP) on carcinoma cells: implication for photodynamic therapy. Toxicology 149: 69-74, 2000.
34. Yokota T, Ikeda H, Inokuchi T, Sano K and Koji T: Enhanced cell death in NR-S1 tumor by photodynamic therapy: possible involvement of Fas and Fas ligand system. Lasers Surg Med 26: 449-460, 2000.

35. Rehemtulla A, Hamilton CA, Chinnaiyan AM and Dixit VM: Ultraviolet radiation-induced apoptosis is mediated by activation of CD-95 (Fas/APO-1). J Biol Chem 272: 2578325786, 1997

36. Chinnaiyan AM, O'Rourke K, Tewari M and Dixit VM: FADD, a novel death domain-containing protein, interacts with the death domain of Fas and initiates apoptosis. Cell 81: 505-512, 1995.

37. Ali SM, Chee SK, Yuen GY and Olivo M: Hypericin induced death receptor-mediated apoptosis in photoactivated tumor cells. Int J Mol Med 9: 601-616, 2002.

38. Thornberry NA and Lazebnik Y: Caspases: enemies within. Science 281: 1312-1316, 1998.

39. Fritsch C, Goerz G and Ruzicka T: Photodynamic therapy in dermatology. Arch Dermatol 134: 207-214, 1998.

40. Lam M, Oleinick NL and Nieminen AL: Photodynamic therapyinduced apoptosis in epidermoid carcinoma cells. Reactive oxygen species and mitochondrial inner membrane permeabilization. $\mathbf{J}$ Biol Chem 276: 47379-47386, 2001

41. Kessel D and Luo Y: Photodynamic therapy: a mitochondrial inducer of apoptosis. Cell Death Differ 6: 28-35, 1999.

42. Granville DJ, Carthy CM, Jiang H, Shore GC, McManus BM and Hunt DW: Rapid cytochrome c release, activation of caspases 3, 6, 7 and 8 followed by Bap31 cleavage in HeLa cells treated with photodynamic therapy. FEBS Lett 437: 5-10, 1998.

43. Morgan J and Oseroff AR: Mitochondria-based photodynamic anti-cancer therapy. Adv Drug Deliv Rev 49: 71-86, 2001.

44. Kennedy JC, Pottier RH and Pross DC: Photodynamic therapy with endogenous protoporphyrin IX: basic principles and present clinical experience. J Photochem Photobiol B 6: 143-148, 1990.

45. Ali SM and Olivo M: Nitric oxide mediated photo-induced cell death in human malignant cells. Int J Oncol 22: 751-756, 2003.

46. Le Bras M, Clement MV, Pervaiz S and Brenner C: Reactive oxygen species and the mitochondrial signaling pathway of cell death. Histol Histopathol 20: 205-219, 2005. 